\title{
CYP2D6*7 Allele
}

National Cancer Institute

\section{Source}

National Cancer Institute. CYP2D6*7 Allele. NCI Thesaurus. Code C46042.

Human CYP2D6*7 allele is located in the vicinity of 22q13.1 and is approximately $4 \mathrm{~kb}$ in length. This allele, a variant form of the CYP2D6 wild-type allele, encodes cytochrome P450 2D6*7 protein. The CYP2D6*7 allele exhibits a clinically-relevant SNP (g.2935A>C) that results in a H324P coding change. This alteration in amino acid sequence causes an alteration of the 3D protein structure in close vicinity to the active site that abolishes the enzymatic activity of the cytochrome P450 2D6*7 protein. 